\title{
E-Commerce to Improve Homemaker Productivity (Women Entrepreneur Empowerment at Meruya Utara, Kembangan District, West Jakarta, Indonesia)
}

\author{
Lucky Nugroho \\ Universitas Mercu Buana \\ lucky.nugroho@mercubuana.ac.id \\ Nurul Hidayah \\ Universitas Mercu Buana \\ nurul.hidayah@mercubuana.ac.id
}

Anees Jane Ali

Universiti Sains Malaysia

aneesali15@yahoo.com

\author{
Ahmad Badawi \\ Universitas Mercu Buana \\ a.badawi@mercubuana.ac.id
}

Accepted: 12 December 2019| Approved: 10 January 2020

\begin{abstract}
Abstrak
Saat ini banyak ibu rumah tangga memiliki bisnis sampingan yang sesuai dengan keterampilan dan hobi mereka. Adapun tujuan dari bisnis sampingan tersebut adalah untuk membantu kebutuhan keuangan rumah tangga mereka. Penelitian sebelumnya telah menunjukkan bahwa ibu rumah tangga yang juga pengusaha perempuan memiliki kontribusi yang signifikan terhadap kesejahteraan keluarga. Namun demikian, terdapat kesulitan dari ibu rumah tangga dalam memasarkan produk dan layanan mereka. Pengabdian ini melaksanakan sosialisasi terkait cara membuat akun e-commerce dan menggunakannya sebagai alternatif untuk menjual produk dan layanan mereka. Selain itu, hasil dari kegiatan layanan masyarakat internasional ini adalah bahwa ibu rumah tangga dapat menjual produk dan layanan mereka melalui e-commerce. Menurut hasil survei pada kegiatan sosialisasi ini, diketahui bahwa hambatan bagi ibu rumah tangga adalah masih rendahnya pendidikan mereka dimana $65 \%$ dari mereka memiliki pendidikan sekolah menengah. Juga, kepemilikan aplikasi internet banking dan mobile banking masih rendah, yaitu
\end{abstract}


35\%. Dengan demikian, kepemilikan yang rendah atas aplikasi internet banking dan mobile banking membuat mereka kesulitan untuk menjual produk dan layanannya melalui e-commerce. Semua peserta sosialisasi menyatakan bahwa kegiatan ini bermanfaat dan menambah pengetahuan mereka. Selanjutnya untuk dapat meningkatkan omset penjualan mereka adalah melalui perbaikan kemasan produk dan layanan mereka untuk membuatnya lebih menarik bagi pembeli.

Kata kunci: Ibu Rumah Tangga, Pengusaha Wanita, Mobile Banking, Internet Banking, ECommerce.

\begin{abstract}
The current phenomenon is that many homemakers have a side business following their skills and hobbies that aim to help their household financial needs. Previous research has shown that homemakers who are also women entrepreneurs have a significant contribution to family welfare. However, there are difficulties from homemakers in marketing their products and services. The method used in this international community service is socialization related to how to create an ecommerce account and use it as an alternative to selling their products and services. Furthermore, the outcome of this service activity is that homemakers can sell their products and services through e-commerce. According to the survey results on this socialization activity, it is known that the obstacle for homemakers is that education is still low, $65 \%$ of them have high school and junior high school education. Also, internet banking and mobile banking application ownership are still small, at 35\%. Thus, the low ownership of internet banking and mobile banking applications has made it difficult for them to sell through e-commerce. All participants of the socialization stated that this activity was useful and increased their knowledge. Next to be able to increase their sales turnover is through improvements to the packaging of their products and services to make it more attractive to buyers.
\end{abstract}

Keyword : Homemaker, Women Enterpreneur, Mobile Banking, Internet Banking, E-commerce

\title{
Introduction
}

The bigger amount of Indonesian economy is supported by the micro, small and medium enterprises (MSME) sector, or in other words, the backbone of the Indonesian economic is MSME (Kristiyanto, 2012; Suci, 2017; Tedjasuksmana, 2014). Furthermore, MSMEs have a value proposition in the economy, where at the time of the economic crisis, this sector is able to survive or not go bankrupt so that they are still capable to run the economy of society continuously (Nugroho et al., 2017). On the other hand, the MSME sector has advantages and has the potential to be further developed through appropriate policy and support from the right institution (Prasetyo, 2008; Rudiantoro, 2012). Currently, the dynamics of e-commerce have spread to various countries, such as the United States and several countries in ASEAN. The growth of e-commerce in ASEAN 
countries, especially Indonesia, has been growing rapidly with the number of internet users reaching 88.1 million (Pusat Kajian Komunikasi-PusKaKom FISIP Universitas Indonesia, 2015), and the value of transactions carried out by the Indonesian people through e-commerce facilities in 2015 reached 150 trillion rupiah (Menteri Perdagangan Enggartiasto Lukita, 2016). Furthermore, the source of this online transaction is not only from transactions in big cities in Indonesia but also from small and rural towns whose people have knowledge about e-commerce and have internet access.

According to previous research, from one of the SMEs who have a real contribution to improve household welfare are homemakers (Hidayah et al., 2018). As well, many homemakers have a profession besides managing their household, but also as an entrepreneur to increase family income (P. M. Dewi, 2012; Haryanto, 2008). Furthermore, according to Nugroho \& Chowdhury (2016), the characteristics of women entrepreneurs are that they choose a business location not far from their domicile or even in their home so that they can control their business and also look after their children (family). With the rapid development of the internet and its benefits can also be used as a tool to market products and services from homemakers, it is necessary to increase the ability of homemakers to be able to know and use it. Marketing is one of the primary keys to increasing sales turnover from entrepreneurs, aside from the quality of their products and services. According to Makarim (2016) and Mcknight \& Chervany (2014), E-Commerce is a trading system that is carried out electronically via the Internet (web-commerce/internet-commerce). Knowledge and use of technology are closely related. However, the collective experience of homemakers is still lower when compared to men's knowledge. This low level of expertise of homemakers can be demonstrated by the MDGs achievement report in 2011, illustrating how women are still behind men so that gender-based development has not been fully achieved. It is known from the aspect of education, and the proportion of literacy of women to men has not reached the target of 100 percent. From the work sector, the contribution of women in the wage sector in the non-agricultural sector only reached 36.6 percent (Alfana et al., 2015). Whereas in terms of empowerment, the ratio of women in parliament has only reached 18.4 percent. Thus the objectives of the socialization and community service activities is enabling the use of e-commerce in homemaker who aims for productive activities. Nevertheless according to (Nugroho et al., 2019), the MDG's program already continued by the SDGs program to solve the problems that not finish yet in the MDGs program that ran in the period (2010-2015). One of the issues that use to be improving in the SDGs program is the boosting of women entrepreneur capacities to become equal with man entrepreneur (Metcalfe, 2011). 
The phenomenon that occurs is that women entrepreneurs have limited market access, difficulties in accessing capital and also low knowledge of women entrepreneurs compared to women entrepreneurs (Kristanto \& Andreas, 2014). Furthermore, knowledge and ability to use online services can solve the limited of market access and also can increase business activities and the impact is the increase sales turnover from women entrepreneurs (Chapman et al., 2002). For this reason, socialization to housewives as financial managers and business partners is needed to increase family income. Therefore the output of understanding e-commerce socialization activities for homemakers are to increase the knowledge and use of homemakers in using e-commerce (Nugroho et al., 2019). The international community services that incorporated between Universitas Mercu Buana, and University Sains Malaysia, aim to increase the capacity of micro and small entrepreneurs, especially women entrepreneurs. One issue related to the limitations of women entrepreneurs is the use of e-commerce platforms to sell their goods and services.

\section{Methods}

The mechanism of implementing international joint community service is through socialization with lectures and discussions. The implementation of this joint community service is aimed at homemakers who are assisted by Kelurahan Meruya Utara, Kembangan District, West Jakarta, Indonesia. Also, the material delivery mechanism is interactive and adapts to the needs of homemakers to increase their side business income. Furthermore, the socialization was held in a full day on 22 August 2019. Neverthelss, the socialization mechanism includes the following matters:

- Knowing the hobbies and skills of homemakers and the side businesses they already have;

- Knowledge sharing related to the definition of e-commerce and how to sell and market products and services from side businesses owned by housewives through e-commerce.

The implementation method used in this activity is the delivery of material that is dialogue. The steps are as follows:

- Explore the abilities and hobbies of homemakers and the side businesses they have;

- Explain the function of e-commerce;

- Communicate the benefits of e-commerce and how to have an e-commerce account.

\section{Result and Discussion}

The implementation of joint international community service with the theme of enhancing the productivity of homemaker by e-commerce between the Faculty of Economics and Business of the 
University of Mercu Buana with the School of Management at Universiti Sain Malaysia was held on August 22, 2019. The place for joint international community service was in Kelurahan Meruya Utara, Kembangan, West Jakarta, which was attended by 20 participants homemakers. The age of the participants and types of side businesses and their education are as follows:

Table 1 Age and Education of Participants in the Socialization

\begin{tabular}{|l|r|r|l|r|r|}
\hline Age & Amount & Percentage & Education & Amount & Percentage \\
\hline $26-35$ & 7 & $35 \%$ & Junior high school & 3 & $15 \%$ \\
\hline $36-45$ & 8 & $40 \%$ & Senior high school & 10 & $50 \%$ \\
\hline $\mathbf{4 6 - 5 5}$ & 5 & $\mathbf{2 5 \%}$ & Bachelor & 7 & $35 \%$ \\
\hline Total & $\mathbf{2 0}$ & $\mathbf{1 0 0 \%}$ & Total & $\mathbf{2 0}$ & $\mathbf{1 0 0 \%}$ \\
\hline
\end{tabular}

Furthermore, following table 1 above, it is known that the majority of participants in the socialization are in the productive age of between 26 to 45 years, as many as $75 \%$ of the participants. In terms of education, the majority of participants are high school, which is $50 \%$ of the participants. Also, homemakers of productive age tend to have more concern to improve the welfare of their families which is also supported by their higher knowledge. Furthermore, the highest level of education of a homemaker and the most number is homemaker aged between 26 to 35 years, with an amount 5 homemaker (table 2).

The desire to increase knowledge aimed at improving the income of side businesses from homemaker is dominated by homemaker at productive ages. This is in line with previous research also states the same thing where innovation and creativity tend to be present at a productive age (Heunks, 1998; Mumford \& Gustafson, 1988), therefore, the target of this socialization is housewives at a productive age and have side businesses. Side businesses developed at a productive age have a higher success rate than businesses developed in old age. There are many incidents of business done at the age of 50 years have a greater chance of failure when compared to businesses that have been initiated since a young age (Iswanti \& Fathiyah, 2014; Widyowati \& Hadjam, 2014). Homemakers as women entrepreneurs have a significant role in supporting family life, especially looking for additional income to cover unexpected expenses. Some essential fees to anticipate are health costs and education costs for children.

Table 2 Education Level Based on Age of Participants

\begin{tabular}{|l|r|r|r|}
\hline Age & Junior High School & Senior High School & Bachelor \\
\hline $26-35$ & 0 & 2 & 5 \\
\hline $36-45$ & 1 & 5 & 2 \\
\hline $46-55$ & 2 & 3 & 0 \\
\hline Total & 3 & 10 & 7 \\
\hline
\end{tabular}


Figure 1 Percentage of Education Level by Age of Participants

Total $=\mathbf{2 0}$

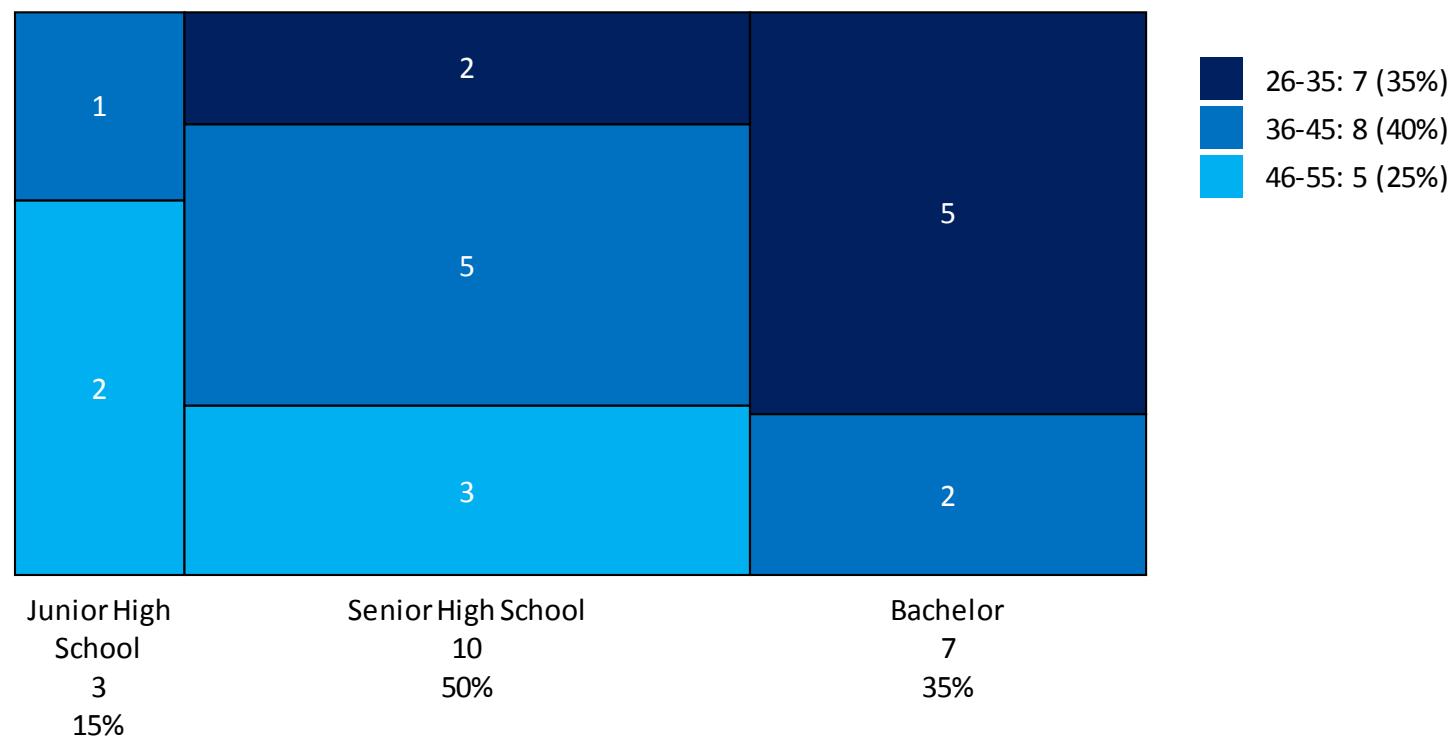

The socialization program began with the delivery that the majority of side businesses carried out by housewives started from their hobbies (Walker et al., 2008). Furthermore, these hobbies can be increased to an expert if they pursue and develop their hobbies with knowledge and skills in the field (Ceddia et al., 2009). Based on the results of a survey that we conducted at this socialization event, all participants have a side business that is also their hobby. Besides, their business sector is synonymous with businesses that can be run by women, that can be carried out by housewives while caring for their families (Mckay, 2001). The support and motivation of the husband have a vital role for women entrepreneurs. The husband's support aims to increase self-confidence and also provide awareness that their partners have sufficient potential and the capacity to become successful women entrepreneurs. Also, cooperation and understanding between husband and wife in managing the household becomes essential. The purpose of opening a business is not only to improve welfare from the material side but also in terms of the psychology of child development and appropriate parenting. A happy family cannot be fulfilled by material needs only, but spiritual aspects are needed for all family members (E. Dewi, 2017; Diener et al., 2010). Therefore the business sector chosen by women entrepreneurs becomes very important to fulfill family responsibilities. The business sector based on survey results at the socialization event is as follows: 
Tabel 3 Type of Side Business from Participant

\begin{tabular}{|l|r|r|}
\hline Side Business & Amount & Percentage \\
\hline Accessories & 4 & $20 \%$ \\
\hline Electronic & 1 & $5 \%$ \\
\hline Food/Beverage & 10 & $50 \%$ \\
\hline Household appliances & 1 & $5 \%$ \\
\hline Bags/Shoes/Clothing & 4 & $20 \%$ \\
\hline Total & $\mathbf{2 0}$ & $\mathbf{1 0 0 \%}$ \\
\hline
\end{tabular}

Following table 3 above, it is known that the side business undertaken by housewives is a food/beverage business, which also becomes their hobby of 50\%. The side business of selling food is synonymous with the expertise of homemakers in meeting the daily needs of their families. Besides, the majority of homemakers have a hobby in cooking so that for them in running a side business that is by the hobby will be more focused. Furthermore, according to Saragih (2017) if the hobbies and expertise are combined, the services or products produced will be of high quality. Also, other business sectors that make up the majority in the side business of homemakers are bagging/shoes/clothing and accessories with a portion of $20 \%$. Side business in the bag/shoes/clothing and accessories sector is also a business that is synonymous with women. The implementation of the socialization went well by providing information that making an account at a bank is the main requirement in selling goods and services using e-commerce media. Furthermore, based on the survey results, it turns out that all participants of the socialization already have an account with a bank. However, only 35\% use mobile and internet banking facilities. Mobile and internet banking users are mostly young at ages 26-35, which is $20 \%$ of total savings account holders.

Table 4 Conventional Bank - Sharia/Islamic Bank Accounts and Mobile \& Internet Banking Users from Homemakers Participating in the program

\begin{tabular}{|c|c|c|c|c|c|}
\hline \multicolumn{4}{|c|}{ Amount } & \multicolumn{2}{|c|}{ Percentage } \\
\hline Age & Bank Account & Mobile \& Internet Banking & Islamic Bank Account & Mobile \& Internet Banking & Islamic Bank Account \\
\hline $26-35$ & 7 & 4 & 0 & $20 \%$ & $0 \%$ \\
\hline $36-45$ & 8 & 3 & 2 & $15 \%$ & $10 \%$ \\
\hline $46-55$ & 5 & 0 & 0 & $0 \%$ & $0 \%$ \\
\hline Total & 20 & 7 & 2 & $35 \%$ & $10 \%$ \\
\hline
\end{tabular}


Figure 2 Users of Conventional Bank - Sharia/Islamic Bank Accounts and Mobile \& Internet Banking Users from Participants

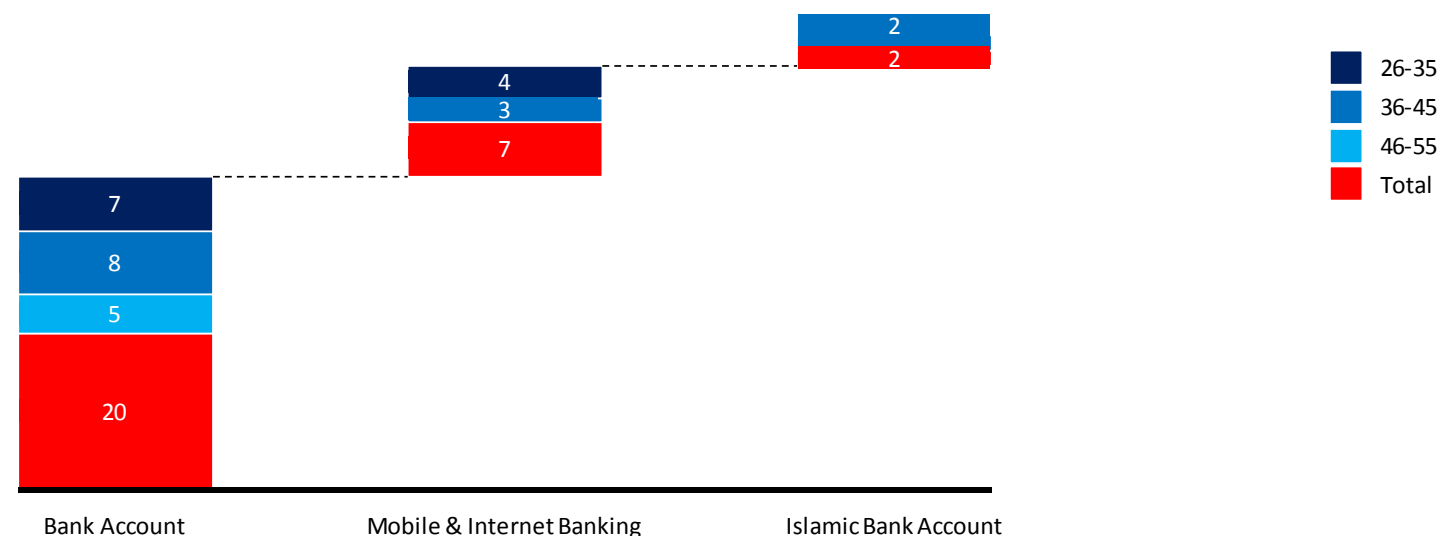

Besides, ownership-based on Figure 2 ownership of Islamic bank accounts is only owned by housewives aged 36-45 years. This shows that not many homemakers have accounts from Islamic banks, which is $10 \%$ of the total homemakers present at the socialization program (table 4). The outreach activities went well, and all participants responded that the E-Commerce outreach program to help sell their products and services was very useful. Empowering homemakers who have hobbies and can commercialize their products and services that aim to increase their sales turnover and need to improve the quality and appearance of the packaging of products and services as portrayed on Figure 3.

Figure 3 The Implementation of Socialization Program

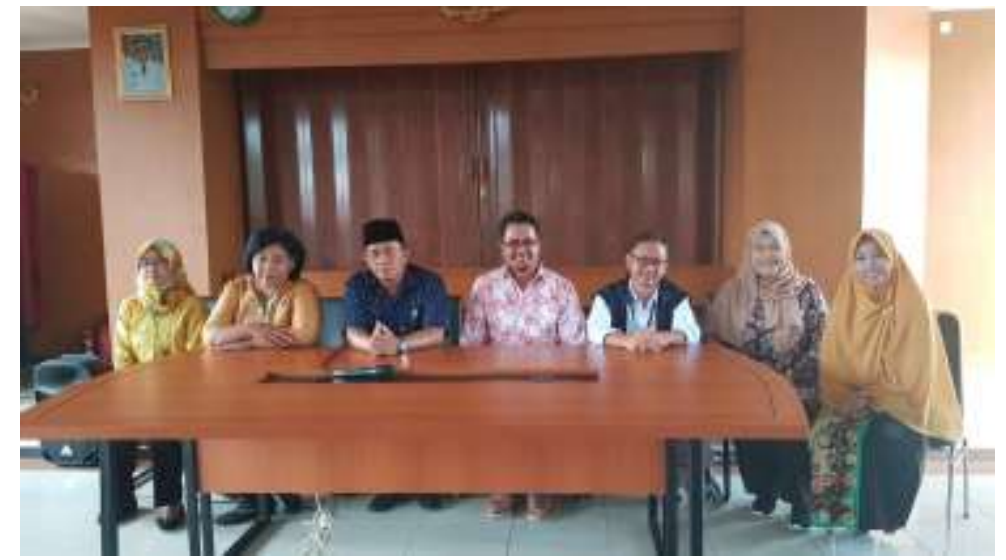




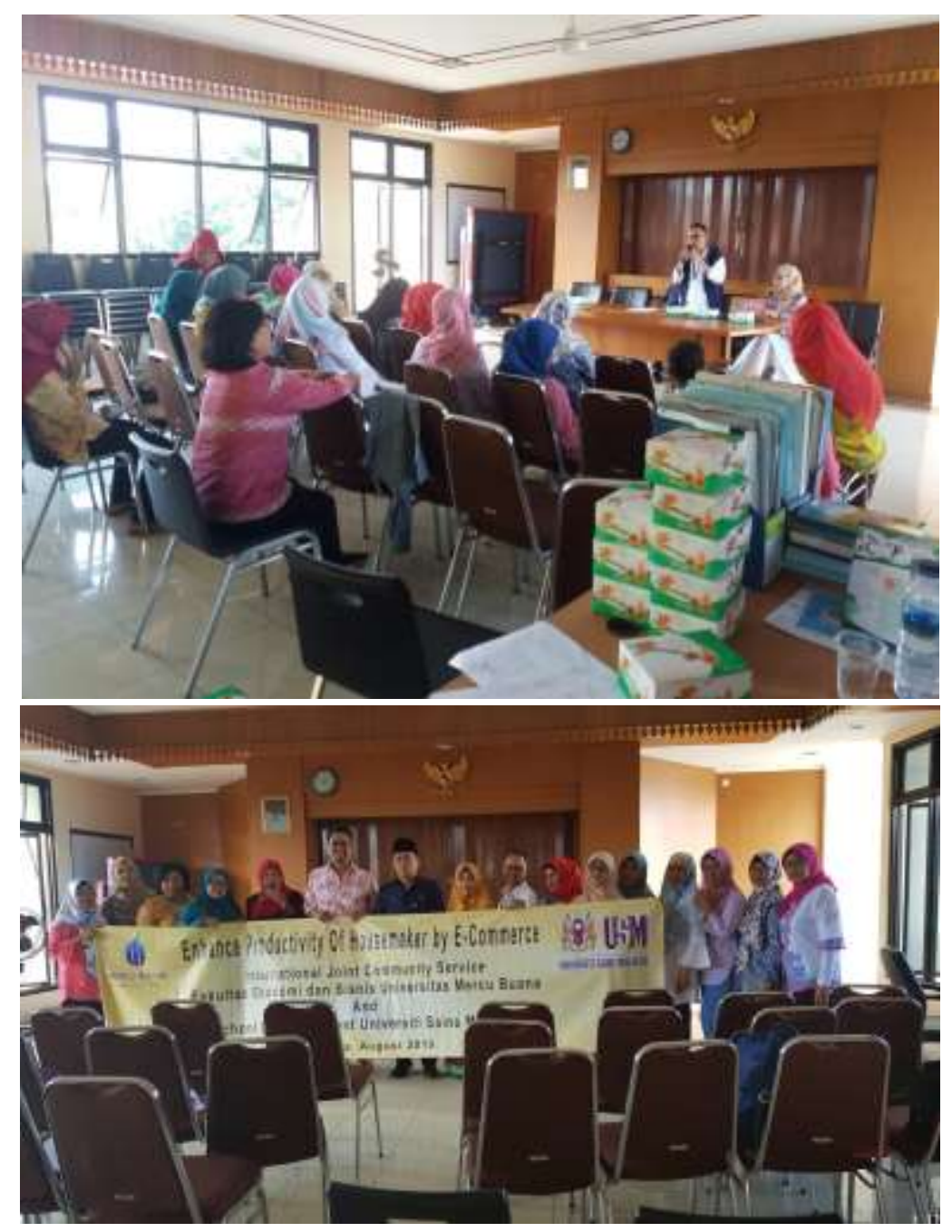

\section{Conclusion}

The role of homemakers (women entrepreneurs) in improving household welfare has a significant role besides their obligation to care for their children. Therefore, the sectors that make up the majority of side businesses of homemakers are food/beverage and bag/shoes/clothing. Furthermore, the socialization of the use of e-commerce to homemakers gets enthusiasm and excellent response from the participants. However, obstacles related to the use of e-commerce are the low education of homemakers and also the small ownership of mobile banking and internet banking as a tool to support financial transactions in marketing their products and services in ecommerce. Also, attractive packaging for their products and services also needs to be improved so that it can provide added value. 


\section{Acknowledgment}

This community service program is implementation of international joint community services between universities in Indonesia and Malaysia contributing to values advantages in terms of exchange of experience, exchange of knowledge, and also the exchange of cases. Furthermore, the implementation of international joint community service between Universitas Mercu Buana and Universiti Sains Malaysia was held in Kelurahan Meruya Utara, Kembangan District, West Jakarta with the theme "Enhance Productivity of Housemaker by E-Commerce" on August 22, 2019. This program also received sponsorship and support from the Universitas Mercu Buana Community Service Center.

\section{References}

Alfana, M. A. F., Fauzan A, D., Laksmiasri, W., \& Rahmaningtias, A. (2015). Dinamika Pembangunan Manusia Berbasis Gender Di Indonesia. In SEMINAR NASIONAL GEOGRAFI UMS 2015 (pp. 1-21).

Ceddia, M. G., Heikkilä, J., \& Peltola, J. (2009). Managing invasive alien species with professional and hobby farmers: Insights from ecological-economic modelling. Ecological Economics, 68(5), 1366-1374. https://doi.org/10.1016/j.ecolecon.2008.09.006

Chapman, P., James-Moore, M., Szczygiel, M., \& Thompson, D. (2002). Building Internet capabilities in SMEs. Logistics Information Management, 13(6), 353-361. https://doi.org/10.1108/09576050010355662

Dewi, E. (2017). Konstruksi Kebahagiaan dalam Bingkai Kecerdasan Spritual. Substantia, 19(2), $133-148$.

Dewi, P. M. (2012). Pastisipasi Tenaga Kerja Perempuan dalam Meningkatkan Pendapatan Keluarga. Jurnal Ekonomi Kuantitatif Terapan, 5(2), 119-124.

Diener, E., Ng, W., Harter, J., \& Arora, R. (2010). Wealth and Happiness Across the World: Material Prosperity Predicts Life Evaluation, Whereas Psychosocial Prosperity Predicts Positive Feeling. Journal of Personality and Social Psychology, 99(1), 52-61. https://doi.org/10.1037/a0018066

Haryanto, S. (2008). Peran Aktif Wanita dalam Peningkatan Pendapatan Rumah Tangga Miskin: Studi Kasus Pada Wanita Pemecah Batu di Pucanganak Kecamatan Tugu Trenggalek. Jurnal Ekonomi Pembangunan, 9(2), 216-227.

Heunks, F. J. (1998). Innovation , Creativity and Success. Small Business Economics, 10(3), $263-$ 272.

Hidayah, N., Nugroho, L., \& Badawi, A. (2018). Socialization and Training for Productive Household Budget for Household Mother In Meruya Selatan Village. ICCD, 1(1), 523-527.

Iswanti, S., \& Fathiyah, K. N. (2014). Pengembangan materi pelatihan menghadapi pensiun bagi karyawan Universitas Negeri Yogyakarta. Jurnal Penelitian Humaniora, 19(1), 96-103. 
Kristanto, A. B., \& Andreas, H. H. (2014). Dari Ibu Rumah Tangga Menjadi Wanita Pengusaha: Hambatan dan Tantangan Dalam Menjalankan Usaha di Sepanjang Hulu Hilir Proses Produksi. In Seminar Nasional dan Call for Paper (Sancall 2014): RESEARCH METHODS AND ORGANIZATIONAL STUDIES (pp. 20-31).

Kristiyanto, A. (2012). Penguatan Kebijakan Publik Usaha Pengentasan Kemiskinan Melalui Pengembangan Industri Mikro. Jurnal Ekonomi Pembangunan: Kajian Masalah Ekonomi Dan Pembangunan, 12(2), 200. https://doi.org/10.23917/jep.v12i2.193

Makarim, E. (2016). Kerangka Kebijakan Dan Reformasi Hukum Untuk Kelancaran Perdagangan Secara Elektronik (E-Commerce) Di Indonesia. Jurnal Hukum \& Pembangunan, 44(3), 314. https://doi.org/10.21143/jhp.vol44.no3.25

Mckay, R. (2001). Women entrepreneurs: Moving beyond family and flexibility. International Journal of Entrepreneurial Behaviour \& Research, 7(4), 148-165. https://doi.org/10.1108/EUM0000000005764

Mcknight, D. H., \& Chervany, N. L. (2014). What Trust Means in E-Commerce Customer Relationships : An Interdisciplinary Conceptual Typology. International Journal of Electronic Commerce, 6(2), 35-59. https://doi.org/10.1080/10864415.2001.11044235

Menteri Perdagangan Enggartiasto Lukita. (2016). Transaksi E-Commerce RI Ditargetkan Capai US\$ 130 Miliar di 2020 - Bisnis Liputan6.com. Retrieved June 28, 2019, from https://www.liputan6.com/bisnis/read/2639692/transaksi-e-commerce-ri-ditargetkan-capai-us130-miliar-di-2020

Metcalfe, B. D. (2011). Women, empowerment and development in arab gulf states: A critical appraisal of governance, culture and national human resource development (hrd) frameworks. Human Resource Development International, 14(2), 131-148. https://doi.org/10.1080/13678868.2011.558310

Mumford, M. D., \& Gustafson, S. B. (1988). Creativity Syndrome: Integration, Application, and Innovation. Psychological Bulletin, 103(1), 27-43.

Nugroho, L., Badawi, A., \& Hidayah, N. (2019). Discourses of sustainable finance implementation in Islamic bank (Cases studies in Bank Mandiri Syariah 2018). International Journal of Financial Research, 10(6), 108-117. https://doi.org/10.5430/ijfr.v10n6p108

Nugroho, L., \& Chowdhury, S. L. K. (2016). Mobile Banking for Empowerment Muslim Women Entrepreneur: Evidence from Asia (Indonesia and Bangladesh). Tazkia Islamic Finance and Business Review, 9(1), 83-100.

Nugroho, L., Hidayah, N., Badawi, A., \& Ali, A. J. (2019). Socialization of Mobile Banking and Internet Banking For Mikro and Small Entrepreneur (Gender and Business Sector PerspectiveKemayoran Night Market Community). ICCD, 2(1), 419-426.

Nugroho, L., Utami, W., Akbar, T., \& Arafah, W. (2017). The challenges of microfinance institutions in empowering micro and small entrepreneur to implementating green activity. International Journal of Energy Economics and Policy, 7(3).

Prasetyo, P. E. (2008). Peran UMKM Dalam Kemiskinan. Jurnal Akmenika Upy, 2(2), 1-13.

Pusat Kajian Komunikasi-PusKaKom FISIP Universitas Indonesia. (2015). Jumlah Pengguna Internet Indonesia Capai 88,1 Juta - Tekno Liputan6.com. Retrieved June 28, 2019, from https://www.liputan6.com/tekno/read/2197413/jumlah-pengguna-internet-indonesia-capai-881- 
E-Commerce to Improve Homemaker Productivity (Women Entrepreneur Empowerment at Meruya Utara, Kembangan District,

West Jakarta, Indonesia) / Lucky Nugroho, et al

juta

Rudiantoro, R. (2012). Kualitas Laporan Keuangan UMKM Serta Prospek Implementasi SAK ETAP. Jurnal Akuntansi Dan Keuangan Indonesia, 9(1), 1-21.

Saragih, R. (2017). Membangun Usaha Kreatif, Inovatif dan Bermanfaat melalui Penerapan Kewirausahaan. Jurnal Kewirausahaan, 3(2), 26-34. Retrieved from http://jklmii.org

Suci, Y. R. (2017). Perkembangan UMKM (Usaha Mikro Kecil dan Menengah ) di Indonesia. Jurnal Ilmiah Cano Ekonomos, 6(1), 51-58.

Tedjasuksmana, B. (2014). Potret Umkm Indonesia Menghadapi Masyarakat Ekonomi Asean 2015. The 7th NCFB and Doctoral Colloquium, 189-202. Retrieved from http://repository.wima.ac.id/982/1/ETR005 - Budianto Tedjasuksmana.pdf

Walker, E., Wang, C., \& Redmond, J. (2008). Women and work- life balance: is home- based business ownership the solution? Equal Opportunities International, 27(3), 258-275. https://doi.org/10.1108/02610150810860084

Widyowati, A., \& Hadjam, R. (2014). Peran Core Self Evaluation dalam Memprediksi Persiapan Pensiun. Humanitas, 11(2), 93-102. 